\title{
Effect of Broad Spectrum Herbicides on Weed Dynamic, Yield and Economics of Soybean Production
}

\author{
Nirmala Bagotiya, Roshan Choudhary*, R.S. Choudhary and Rajesh Chaudhari \\ Department of Agronomy, Rajasthan College of Agriculture, MPUAT, Udaipur, India \\ *Corresponding author
}

\section{A B S T R A C T}

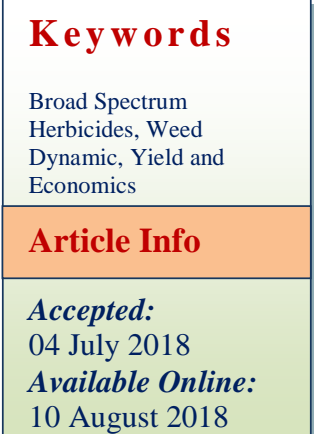

\section{Introduction}

Soybean (Glycine $\max$ L. Merill) popularly known as "wonder crop" of twenty first century is an important oilseed crops. It serves the dual purpose for being grown as an oilseed crop and pulse crop (Thakare et al., 2015). It contains approximately $40-45 \%$ protein and $18-22 \%$ oil and is a rich source of vitamins and minerals. Soybean also helps in maintaining soil fertility and fixes nitrogen symbiotically. The ecological conditions of the state are congenial for cultivation of soybean but the yield is substantially low $(1007 \mathrm{~kg} / \mathrm{ha})$, despite of the best management practices. Being a rainy season crop, the environment is more conducive for excessive weed infestation in soybean. Severe weed

\begin{abstract}
The field experiment was conducted during Kharif, 2017 at Instructional farm of Rajasthan College of Agriculture, Udaipur. Experimental field was mostly dominated by grassy weeds namely; Echinochloa colona, Cynodon dactylon, Digitaria sanguinallis with broad Amarathus viridis and Parthenium hysterophorus and sedges, Cyperus rotundus. The ind the herbicidal treatments were significantly superior over weedy check with all parameters. The tank mix application of imazethapyr $75 \mathrm{~g} / \mathrm{ha}+$ propaquizafop $75 \mathrm{~g} / \mathrm{ha}$ as post-emergence at $21 \mathrm{DAS}$ recorded significantly lower weed density, weed dry weight, maximum weed control efficiency and significantly improved the growth characters, yield and yield attributing characters.
\end{abstract}

competition is one of the major constraints for low productivity of soybean. Weeds in general, cause competition stress on soybean growth, especially during the first 40 days after sowing. Weeds alone are responsible for reduction in weed yield of soybean to the range of 25 to $70 \%$ depending upon the weed flora and intensity (Sandil et al., 2015). Sole application of herbicide as pre or post emergence fails to control diversified and subsequent flushes of weeds effectively (Tuti and Das 2011). Moreover, continuous use of single herbicide is known to result in the evaluation of herbicide resistance in weed species and shift in weed flora (Schutte et al., 2017) So, there is need to apply some new post-emergence herbicides and their tank mix combinations like imazethapyr, propaquizafop 
and quizalofop-ethyl to reduce weed menace and keep the crop free from weed competition during entire critical period of crop growth (Sandil et al., 2015; Parmar et al., 2016 Nirala et al., 2016). Herbicide mixtures provide an opportunity for increasing herbicide efficiency and arresting all complex weed flora shift. Presently, imazethapyr is a very effective post emergence herbicide for controlling broad leaf and some grassy weeds in soybean. But its efficacy has not been tested with propaquizafop, quizalofop-ethyl and pendimethalin for wide spectrum weed control in soybean. Therefore, the present investigation is carried out to assess the efficacy of different herbicide when applied alone or in combination with other herbicides to provide weed free environment during entire growing period of soybean through easy, efficient and economically viable weed management practices.

\section{Materials and Methods}

Experiment was conducted during Kharif, 2017 at Instructional farm of Rajasthan College of Agriculture, Udaipurwhich is situated at $24^{0} 35^{\prime} \mathrm{N}$ latitude and $74^{\circ} 42^{\prime} \mathrm{E}$ longitude. The region falls under the agro climatic zone IVa of Rajasthan i.e. Sub-humid Southern Plain and Aravali Hills of Rajasthan. The experiment was arranged in a randomized block design consisting of nine treatment combinations i.e., weedy check, imazethapyr $100 \mathrm{~g} / \mathrm{ha}$ PoE 15 DAS, pendimethalin 1000 g/ha PE, quizalofop-ethyl $75 \mathrm{~g} / \mathrm{ha}$ PoE 15 DAS, propaquizafop $100 \mathrm{~g} / \mathrm{ha}$ PoE 15 DAS, imazethapyr + imazamox (RM) $70 \mathrm{~g} / \mathrm{ha} \mathrm{PoE}$ 15 DAS, imazethapyr + pendimethalin (RM) $1000 \mathrm{~g} / \mathrm{ha} \mathrm{PE}$, imazethapyr $75 \mathrm{~g} / \mathrm{ha} \mathrm{PoE}+$ quizalofop-ethyl $60 \mathrm{~g} / \mathrm{ha}$ PoE 21 DAS (TM) and imazethapyr $75 \mathrm{~g} /$ ha + propaquizafop 75 g/ha PoE 21 DAS (TM)replicated thrice. A knapsack sprayer fitted with a flat fan nozzle was used for herbicide application. Total rainfall received during crop growing season was $648.0 \mathrm{~mm}$. The soil of the experimental site was low in available nitrogen, medium in organic carbon and phosphorus and high in available potassium. Soybean variety RKS-24 (Pratap Raj 24) was used as experimental material developed at ARS, Kota (Rajasthan).

\section{Results and Discussion}

\section{Effect on weeds}

The results showed that weed control methods markedly reduced crop-weed competition. The experimental data revealed that postemergence application of imazethapyr $75 \mathrm{~g} /$ ha + propaquizafop $75 \mathrm{~g} / \mathrm{ha}$ at $21 \mathrm{DAS}$ resulted the lowest density of monocot $\left(2.78 / \mathrm{m}^{2}\right)$, dicot $\left(1.59 / \mathrm{m}^{2}\right)$ and total weeds $\left(3.13 / \mathrm{m}^{2}\right)$ at 30 DAS compared to weedy check $(8.42,6.65$ and $10.71 / \mathrm{m}^{2}$ ) respectively. At 30 and 60 DAS, minimum dry matter of both monocot and dicot weeds were recorded under application of imazethapyr $75 \mathrm{~g} /$ ha + propaquizafop $75 \mathrm{~g} / \mathrm{ha}$. Among dicots, the next treatment in the order of superiority imazethapyr $75 \mathrm{~g} / \mathrm{ha}+$ quizalofop-ethyl 60 $\mathrm{g} / \mathrm{ha}$ as PoE at both the stages was found best.

Maximum weed control efficiency of monocot, dicot and total weeds was observed with post emergence application of imazethapyr $75 \mathrm{~g} /$ ha + propaquizafop $75 \mathrm{~g} / \mathrm{ha}$. The herbicide combination of imazethapyr + propaquizafop and imazethapyr + quizalofopethyl were more effective and had activity on a wide spectrum of weeds including grasses and broadleaf weeds in soybean thus their performance is directly proportional to the weed control efficiency. The higher weed control efficiency under these treatments could be attributed to the lower weed population and total weed dry matter as well. These results were corroborated with the finding of Habimana et al., (2013), Sandil et al., (2015), Panda et al., (2015) and Patel et al., (2016) (Table 1). 
Table.1 Effect of herbicides on weed dry matter and weed control efficiency at 60 DAS

\begin{tabular}{l} 
Treatments \\
\hline Imazethapyr $100 \mathrm{~g} / \mathrm{ha}$ PoE at 15 DAS \\
Pendimethalin $1000 \mathrm{~g} / \mathrm{ha}$ PE \\
Quizalofop-ethyl $75 \mathrm{~g} / \mathrm{ha}$ PoE at $15 \mathrm{DAS}$ \\
Propaquizafop $100 \mathrm{~g} / \mathrm{ha}$ PoE at $15 \mathrm{DAS}$ \\
\hline Imazethapyr + imazamox (RM) $70 \mathrm{~g} / \mathrm{ha}$ PoE at 15 DAS \\
\hline Imazethapyr + pendimethalin (RM) 1000 g/ha PE \\
\hline Imazethapyr 75 g/ha PoE + quizalofop-ethyl $60 \mathrm{~g} / \mathrm{ha}$ (TM) PoE at 21 DAS \\
\hline Imazethapyr $75 \mathrm{~g} / \mathrm{ha}+$ propaquizafop $75 \mathrm{~g} / \mathrm{ha}$ (TM) PoE at $21 \mathrm{DAS}$ \\
\hline Weedy check \\
\hline SEm \pm \\
\hline CD (P=0.05)
\end{tabular}

\begin{tabular}{|c|c|c|c|c|c|}
\hline \multicolumn{2}{|c|}{ Weed dry matter $\left(\mathrm{g} / \mathrm{m}^{2}\right)$} & at 60 DAS & \multicolumn{3}{|c|}{ Weed control efficiency $(\%)$} \\
\hline Monocots & Diocots & Total & Monocots & Diocots & Total \\
\hline 11.79 & 7.31 & 19.10 & 76.43 & 76.65 & 76.52 \\
\hline 13.48 & 11.54 & 25.02 & 73.06 & 62.88 & 69.24 \\
\hline 8.30 & 20.48 & 28.78 & 83.41 & 34.12 & 64.61 \\
\hline 6.37 & 12.34 & 18.71 & 87.26 & 60.13 & 76.93 \\
\hline 13.01 & 7.90 & 20.91 & 73.99 & 74.79 & 74.30 \\
\hline 11.61 & 10.34 & 21.94 & 76.78 & 66.99 & 73.01 \\
\hline 8.86 & 3.05 & 11.91 & 82.32 & 90.25 & 85.36 \\
\hline 5.16 & 1.43 & 6.59 & 89.64 & 95.45 & 91.89 \\
\hline 50.20 & 31.21 & 81.41 & 0.00 & 0.00 & 0.00 \\
\hline 0.74 & 0.68 & 0.92 & - & - & - \\
\hline 2.21 & 2.04 & 2.76 & - & - & - \\
\hline
\end{tabular}

Table.2 Effect of herbicides on yield attributes of soybean

\begin{tabular}{|c|c|c|c|c|c|c|c|c|}
\hline Treatments & $\begin{array}{l}\text { Number of } \\
\text { pods /plant }\end{array}$ & $\begin{array}{l}\text { Number of } \\
\text { seeds/pod }\end{array}$ & $\begin{array}{l}\text { Pod length } \\
\quad(\mathrm{cm})\end{array}$ & $\begin{array}{l}\text { Test weight } \\
\text { (g) }\end{array}$ & $\begin{array}{c}\text { Seed } \\
\text { Yield } \\
\text { (kg/ha) }\end{array}$ & $\begin{array}{c}\text { Haulm } \\
\text { Yield } \\
\text { (kg/ha) }\end{array}$ & $\begin{array}{l}\text { Net returns } \\
\qquad(₹ / h a)\end{array}$ & $\begin{array}{l}\text { B C } \\
\text { ratio }\end{array}$ \\
\hline Imazethapyr $100 \mathrm{~g} / \mathrm{ha}$ PoE at $15 \mathrm{DAS}$ & 24.70 & 2.30 & 4.67 & 76.70 & 1396 & 1703 & 29169 & 1.34 \\
\hline Pendimethalin 1000 g/ha PE & 29.86 & 2.36 & 4.86 & 80.36 & 1518 & 1874 & 33960 & 1.58 \\
\hline Quizalofop-ethyl $75 \mathrm{~g} / \mathrm{ha}$ PoE at 15 DAS & 29.16 & 2.34 & 4.81 & 80.16 & 1438 & 1755 & 30848 & 1.43 \\
\hline Propaquizafop 100 g/ha PoE at 15 DAS & 26.70 & 2.30 & 4.74 & 79.60 & 1348 & 1692 & 28843 & 1.41 \\
\hline $\begin{array}{l}\text { Imazethapyr + imazamox (RM) } 70 \text { g/ha PoE at } 15 \\
\text { DAS }\end{array}$ & 27.12 & 2.32 & 4.72 & 79.93 & 1618 & 1732 & 36769 & 1.71 \\
\hline Imazethapyr + pendimethalin (RM) 1000 g/ha PE & 27.80 & 2.40 & 4.76 & 80.12 & 1462 & 1709 & 31181 & 1.42 \\
\hline $\begin{array}{l}\text { Imazethapyr } 75 \text { g/ha PoE + quizalofop-ethyl } 60 \text { g/ha } \\
\text { (TM) PoE at } 21 \text { DAS }\end{array}$ & 31.98 & 2.46 & 4.90 & 83.99 & 1678 & 1949 & 38303 & 1.70 \\
\hline $\begin{array}{l}\text { Imazethapyr } 75 \text { g/ ha + propaquizafop } 75 \text { g/ha (TM) } \\
\text { PoE at } 21 \text { DAS }\end{array}$ & 32.10 & 2.40 & 4.96 & 85.10 & 1724 & 2182 & 41478 & 1.92 \\
\hline Weedy check & 16.67 & 2.18 & 4.08 & 50.67 & 631 & 846 & 3241 & 0.16 \\
\hline SEm \pm & 1.18 & 0.04 & 0.15 & 0.74 & 59.81 & 82.33 & 1910 & - \\
\hline $\mathrm{CD}(\mathrm{P}=0.05)$ & 3.53 & 0.13 & 0.46 & 2.23 & 179.32 & 246.82 & 5726 & - \\
\hline
\end{tabular}


Propaquizafop is a post emergence, systemic and selective herbicide use to control of annual and perennial grassy weeds in broadleaf crops. It belongs to aryloxphenoxypropionics (APPs) group of herbicide and systematically gets translocated to plant meristems. Herbicidal gets absorbed by the foliage within one hour of spraying and inhibits fatty acid synthesis (ACCease).Results corroborate with the findings of Renjith and Sharma et al., (2014), Ramprakash et al., (2016) Parmar et al., (2016), Nagre et al., (2017).

\section{Effect on crop}

Imazethapyr $75 \mathrm{~g} / \mathrm{ha}+$ propaquizafop $75 \mathrm{~g} / \mathrm{ha}$ treatment recorded maximum number of branch/plant, number of pods/plant, pod length and test weight. The maximum seed yield (1724 kg/ha) was recorded under imazethapyr $75 \mathrm{~g} / \mathrm{ha}+$ propaquizafop $75 \mathrm{~g} / \mathrm{ha}$ over all other weed control treatments. Tank mix application of imazethapyr $75 \mathrm{~g} / \mathrm{ha}+$ propaquizafop $75 \mathrm{~g} /$ ha resulted in maximum haulm yield $(2182 \mathrm{~kg} / \mathrm{ha})$ which was statistically at par with imazethapyr $75 \mathrm{~g} / \mathrm{ha}+$ quizalofop-ethyl $60 \mathrm{~g} / \mathrm{ha}$. Alike seed and haulm yield biological yield (3906 kg/ha) was also recorded maximum under imazethapyr $75 \mathrm{~g} / \mathrm{ha}+$ propaquizafop $75 \mathrm{~g} / \mathrm{ha}$.It is established fact that least crop weed competition during the early phase of crop growth exerts an important regulatory function on complex process of yield formation due to better availability of water, space and nutrient to the crop plant. It also helps in improving aeration and nutrient uptake by plant resulting in higher metabolic activity. The better expression of yield attributes in herbicide and manually weeded plots might be due to poor resurgence frequency and growth of weeds in these treatments. Hence, weeds were unable to compete with the crop plants for different growth factors. Improvement in yield attributes occurred when weeds were controlled in the early growth stages particularly during critical growth period either manually or chemically, which scaled down competition and created congenial micro-environment for better establishment and growth of the crop (Table 2).

Post-emergence application of imazethapyr $75 \mathrm{~g} / \mathrm{ha}+$ propaquizafop $75 \mathrm{~g} / \mathrm{ha}(\mathrm{TM})$ at 21 DAS recorded the highest seed yield (1724 $\mathrm{kg} / \mathrm{ha}$ ) and net return ( ₹ 41478) however, this treatment was at par with imazethapyr + quizalofop-ethyl and imazethapyr + imazamox. Imazethapyr + propaquizafop did not cause any phytotoxicity to soybean crop. Similar findings was also reported by Bhan and Kewat, (2002) and Prachand et al., 2014.

\section{References}

Bhan, M. and Kewat, M.L. 2002. Economics of herbicidal weed control in soybean [Glycine max (L.) Merrill]. Indian Journal of Weed Science 34:139-140.

Nagre, B. S., Kumble, A. B., Danawale, N. J. and Dhonde, M. B. 2017. Crop geometry and weed management effect on weed dynamics in soybean. Indian Journal of Weed Science 49: 95-97.

Nirala, H., Sonit, A. and Rathore, A. L. 2016.Post-emergence herbicides for weed control in blackgram. Indian Journal of Weed Science 48: 76-78.

Parmar, P. S., Jain, N., Kumar, D. and Solanki, R. 2016. Efficacy of different herbicides for weed control in soybean. Indian Journal of Weed Science 48: 453-454.

Prachand, S., Kubde, K. J. and Bankar, S. 2014. Effect of chemical weed control on weed parameters, growth, yield attributes, yield and economics in Soybean [Glycine $\max$ (L.) Merril.]. American-Eurasian Journals of 
Agriculture \& Environmental Science 14: 698-701.

Ramprakash, T., Madhavi, M. and Yakadri, M. 2016. Dissipation and persistence of propaquizafop in soil, plant and rhizomes in turmeric and its effect on soil properties. Nature Environment and Pollution Technology 15: 1217-1220.

Sandil, M. K., Sharma, J. K., Sanodiya, P. and Pandey, A. 2015. Bio-efficacy on tankmixed propaquizafop and imazethapyr against weeds in soybean. Indian Journal of Weed Science 47: 158-162.

Schütte, G., Eckerstorfer, M., Rastelli, V., Reichenbecher, W., Restrepo, S., Ruohonen, M., Anne, S. and Mertens,
M. 2017. Herbicide resistance and biodiversity: agronomic and environmental aspects of genetically modified herbicide-resistant plants. Environmental Sciences Europe 29: 512.

Thakare, S. S., Deshmukh, J. P., Shingrup, P. V., Pawar, P. M. and Ghlop, A. N. 2015 Efficacy of different new herbicides against weed flora in soybean (Gycine max L.) Plant Archives 15: 217-220.

Tuti, M. D. and Das, T. K. 2011. Sequential application of metribuzin on weed control, growth and yield of soybean (Glycine max). Indian Journal of Agronomy 56: 57-61.

\section{How to cite this article:}

Nirmala Bagotiya, Roshan Choudhary, R.S. Choudhary and Rajesh Chaudhari. 2018. Effect of Broad Spectrum Herbicides on Weed Dynamic, Yield and Economics of Soybean Production. Int.J.Curr.Microbiol.App.Sci. 7(08): 157-161. doi: https://doi.org/10.20546/ijcmas.2018.708.020 